\title{
Flowering and fruiting of cv. Pakistan mulberry under saline soil conditions in Egypt
}

Ahmed A. EL OBEIDY

Department of Fruit Horticulture, Faculty of Agriculture, Cairo University, Giza, Egypt

elobeidy@hotmail.com
${ }^{*}$ Correspondence and reprints

Received 28 February 2005 Accepted 1 September 2005

Fruits, 2005, vol. 60, p. 405-411 (C) 2005 Cirad/EDP Sciences All rights reserved DOI: $10.1051 /$ fruits:2005046

RESUMEN ESPAÑOL, p. 411

\section{Flowering and fruiting of cv. Pakistan mulberry under saline soil conditions in Egypt.}

Abstract - Introduction. The introduction of the elite variety of black mulberry under saline conditions could have a significant long-term impact on development in the impoverished rural areas. Materials and methods. Plants of the Pakistan mulberry cultivar were propagated by budding on Japanese mulberry seedlings. Trees were cultivated under saline soil conditions in Egypt. Results and discussion. Trees successfully bloomed and produced fruits after 2 years of budding. Intensive flowering and fruiting occurred in the third seasons. Four to six catkins developed on each branch or spur. Each catkin consisted of an average of 315 flowerlets, stacked on a peduncle. Fruits were found to be parthenocarpic. During ripening, fruits changed from the green stage to the ruby-red stage, then to the dark-purple stage. Fruit ripening began in the second week of March and extended to the third week of April. Ripe fruit ranged from ( 7.3 to 11.8$) \mathrm{cm}$ in length and from $(1.3$ to 1.5$) \mathrm{cm}$ in diameter. Fruit weight ranged from (8.3 to 10.2$) \mathrm{g}$. TSS of the fruit juice ranged from (13.0 to 17.5$){ }^{\circ} \mathrm{Brix}$, while $\mathrm{pH}$ ranged from 3.1 to 3.36 . Fruits contained $10.2 \%$ carbohydrates, $1.4 \%$ protein and $1.2 \%$ fibers. Fruits were found to be a good source of iron, potassium, calcium and phosphorus. Fruits contained a medium level of vitamin C. Average crop production per tree in the second and third seasons was (51 and 96) kg, respectively. Ripe fruits could not survive more than 5 days' storage at room temperature, but survived 3 weeks of cold storage.

\section{Egypt / Morus nigra / plant introduction / soil salinity}

\section{Floraison et fructification du mûrier cv. 'Pakistan' sur sol salin en Égypte.}

Résumé - Introduction. L'introduction d'une variété élite de mûre noire en zones caractérisées par des sols salins pourrait avoir, à long terme, un impact significatif sur le développement de secteurs ruraux défavorisés. Matériel et méthodes. Des plants du mûrier cv. 'Pakistan' ont été propagés par greffe sur de jeunes plantules de mûrier de type japonais. Les arbres ont été cultivés sur sols salins en Égypte. Résultats et discussion. Les arbres ont bien fleuri et ont fructifié 2 ans après leur greffage. Des floraisons et fructifications intensives ont eu lieu lors de la troisième saison. Quatre à six chatons se sont développés sur chaque branche ou rameau. Chaque chaton a été composé en moyenne de 315 fleurs élémentaires empilées sur une hampe florale. Les fruits se sont révélés être parthénocarpiques. Pendant leur maturation, la couleur des fruits a évolué du stade vert au stade rouge rubis, puis au stade pourpre foncé. La maturation du fruit a commencé la deuxième semaine de mars et s'est prolongée jusqu'à la troisième semaine d'avril. Le fruit mûr a mesuré $(7,3$ à 11,8$) \mathrm{cm}$ de long et $(1,3$ à 1,5$) \mathrm{cm}$ de large. Son poids a varié de $(8,3$ à 10,2) $\mathrm{g}$. La valeur des SST du jus de fruit a varié de $(13,0$ à 17,5$){ }^{\circ}$ Brix, alors que le pH s'échelonnait de 3,1 à 3,36. Les fruits ont présenté 10,2 \% d'hydrates de carbone, 1,4\% de protéine et 1,2\% de fibres. Ils se sont révélés être une bonne source de fer, de potassium, de calcium et de phosphore. Leur teneur en vitamine $\mathrm{C}$ a été moyenne. La production moyenne par arbre a été de $51 \mathrm{~kg}$ la deuxième saison et de $96 \mathrm{~kg}$ la troisième saison. Le stockage des fruits mûrs n'a pas pu dépasser $5 \mathrm{j}$ à température ambiante, mais, au froid, il a pu atteindre 3 semaines.

\section{Égypte / Morus nigra / introduction de plantes / salinité du sol}




\section{Introduction}

Mulberry (Morus sp.) is a very important crop for fruits, silkworm and livestock feed and timber, as well as being an excellent amenity tree [1]. Mulberry fruits can be eaten fresh, preserved, dried for winter use or made into pies, tarts, jellies, jam, puddings, syrups, sauces and ice cream. Dried fruits are used like dried figs and raisins for snacks and in puddings, cookies, muffins and confections.

The black mulberry (Morus nigra L.) is a widely grown fruit, native to western Asia [2]. Black mulberry fruits are large and juicy, with a good balance of sweetness and tartness that makes the best flavored species of mulberry [3].

Black mulberry fruit is not only known for nutritional qualities and flavor, but also for traditional use in natural medicine. Black mulberry has a high content of active therapeutic compounds. Numerous authors have reported that Diabetes mellitus type II can be controlled by black mulberry [4]. The fruit is also used to treat mouth, tongue and throat inflammations [3].

The Pakistan mulberry cultivar evolved in Islamabad, Pakistan [19]. Several species of mulberry have been domesticated and innumerable cultivars selected over many centuries, so the plant's great range is not surprising. Generally, mulberry is a diploid plant with 28 chromosomes $(2 n=28)$. However, $M$. nigra is dexoploid $(2 n=308)$, with the largest number of chromosomes among phanerogams [7].

Pakistan mulberry plants were propagated by budding on Japanese mulberry seedlings. Mulberries can be grown from seed or vegetatively propagated. Mulberries are also frequently grafted, especially fruiting cultivars. Methods vary from region to region, reflecting the plant's great ecological and genetic range. In Japan, mulberry propagation is generally carried out by grafting and by cuttings [7].

Mulberry tree is reported to tolerate salt, drought and poor soil [5].

Salinity is a common problem in the Middle East and North Africa because of high evaporation and low rainfall. Salinity has long been recognized as one of the most critical issues facing the area [6]. Cultivating plants with potential of commercial utilization under saline conditions such as mulberry can have a significant long-term impact on development in the impoverished rural areas.

There is a very rich store of genetic resources for mulberry that could be exploited for fruit production [7]. A large number of black mulberry varieties are grown in several geographical regions. The identifying and introducing elite or promising varieties of black mulberry could ultimately have a direct effect on crop quality under adverse conditions.

The objectives of our research were to introduce and to cultivate the Pakistan black mulberry cultivar under saline soil conditions. Flowering and fruiting were evaluated under the new environment.

\section{Materials and methods}

\subsection{Tree establishment}

Japanese mulberry was used as rootstock for the Pakistan mulberry cultivar. Thirty plants of 1-year-old Japanese mulberry propagated by cuttings were transplanted into an orchard located in Northern Cairo, Egypt, in spring, 1998. Distances between rows and trees in the row were $5 \mathrm{~m} \times 5 \mathrm{~m}$. The orchard soil was sandy with 4.2 EC (Electrical Conductivity).

Scion wood was taken from a female Pakistan mulberry tree. T budding was carried out in January, 1999. The central leader training system was used to train trees.

Cultural practices were developed 2 years after budding. The first irrigation was done on the first of January, then every 2 weeks until September. During the growing season, trees were fertilized with fertilizer NPK (10:10:10) every month [8].

\subsection{Catkin isolation}

In the last week of December, ten branches or parts of branches in each replicate were bagged with $(20 \times 45) \mathrm{cm}$ bags [9]. The bags were removed in the middle of March. 


\subsection{Morphological measurements}

Number of catkins per newly developed growth or spur, increase in catkin length and diameter, number of leaves developed per new branch, number of fruitlets per fruit, fruit length and diameter and fruit weight were recorded. To determine the average number of fruitlets per fruit, fruitlets were picked gently from ruby-red stage fruits with small scalpels. Ten morphological measurements were recorded in each replicate. Morphological measurements were compared during the second and third seasons.

\subsection{Fruit yield}

Ripe fruits were harvested by spreading a sheet on the ground and shaking the limbs of the trees, every 2 days during fruiting. Yields were assessed in the 2002 and 2003 seasons by weighing the amount of ripe fruit produced by each tree.

\subsection{Fruit storage}

Fruits at the dark purple or ruby-red stages were collected and bagged in separate boxes. Fruits were bagged in 40 small wooden boxes in three layers. Boxes were stored at $25^{\circ} \mathrm{C}$ (room temperature) or $3{ }^{\circ} \mathrm{C}$ (cold temperature). Fruit samples were assessed every 2 days for spoilage and fruit odor and flavor.

\subsection{Chemical analysis}

Extract of dried fruit samples was used for colorimetric determination of total carbohydrates at $490 \mathrm{~nm}$. Concentration of total carbohydrates was calculated by a calibration curve established with standard solution of pure glucose [10].

The total nitrogen was determined in the dry fruit samples using $\mathrm{H}_{2} \mathrm{SO}_{4}$ and $\mathrm{H}_{2} \mathrm{O}_{2}$ as described by Cottenie [11]. Nitrogen content was determined in the digested solution by the modified Microkjeldahl method as described by Plummer [12]. A factor of 6.25 was used to calculate the crude protein content.

A Nuclear Magnetic Resonance (NMR) analyzer was used to determine the fat con- tent in the fruits [13]. The unit was calibrated using the data obtained by solvent extraction.

Fiber was determined according to the procedure described by AOAC [14, 15].

Phosphorus, potassium, calcium and iron contents were determined in the dry fruit samples by Flame Atomic Absorption Spectrophotometry [16].

The method of titration with dichlorophenolindophenol (DCPIP) was used to determine the ascorbic acid content in the fresh fruit samples. Ascorbic acid reacts with DCPIP, changing the color from blue to colorless. They react in a 1:1 fashion, so if a known quantity of DCPIP solution reacts with the fruit extract, the quantity of DCPIP used gives a direct measurement of the quantity of ascorbic acid present [17].

In each replicate, ten samples were taken for chemical analysis, which were compared during the second and third seasons.

\subsection{Sensory evaluation}

Sensory evaluation was conducted by a taste panel set consisting of 25 people. The panel was used to assess fruit taste during the different ripening stages and after different storage treatments.

\subsection{Statistical analysis}

A completely randomized design was used, and mean comparisons were made using the Duncan's Multiple Range test at the 5\% significance level [18]. Trees were randomly divided into six replicates. Each replicate consisted of five trees.

For each fruit storage experiment, four replicates were used. Each replicate consisted of five boxes.

\section{Results and discussion}

Under the saline soil conditions of our experiment, the Pakistan mulberry trees cultivated successfully bloomed and produced fruits. 


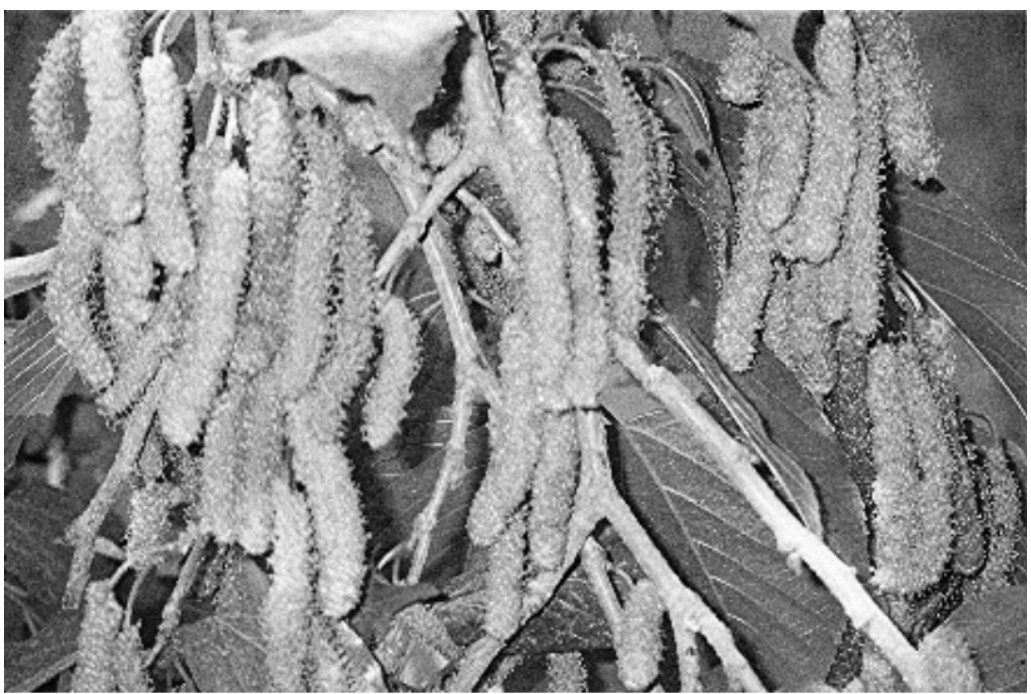

Figure 1.

Fruits of Pakistan mulberry at different stages in the middle of March (Egypt).

Figure 2.

Increase in catkin length and diameter for Morus nigra cv. Pakistan during flowering and fruiting. Values in each group labeled with the same letter are not significantly different $(P>0.05)$.
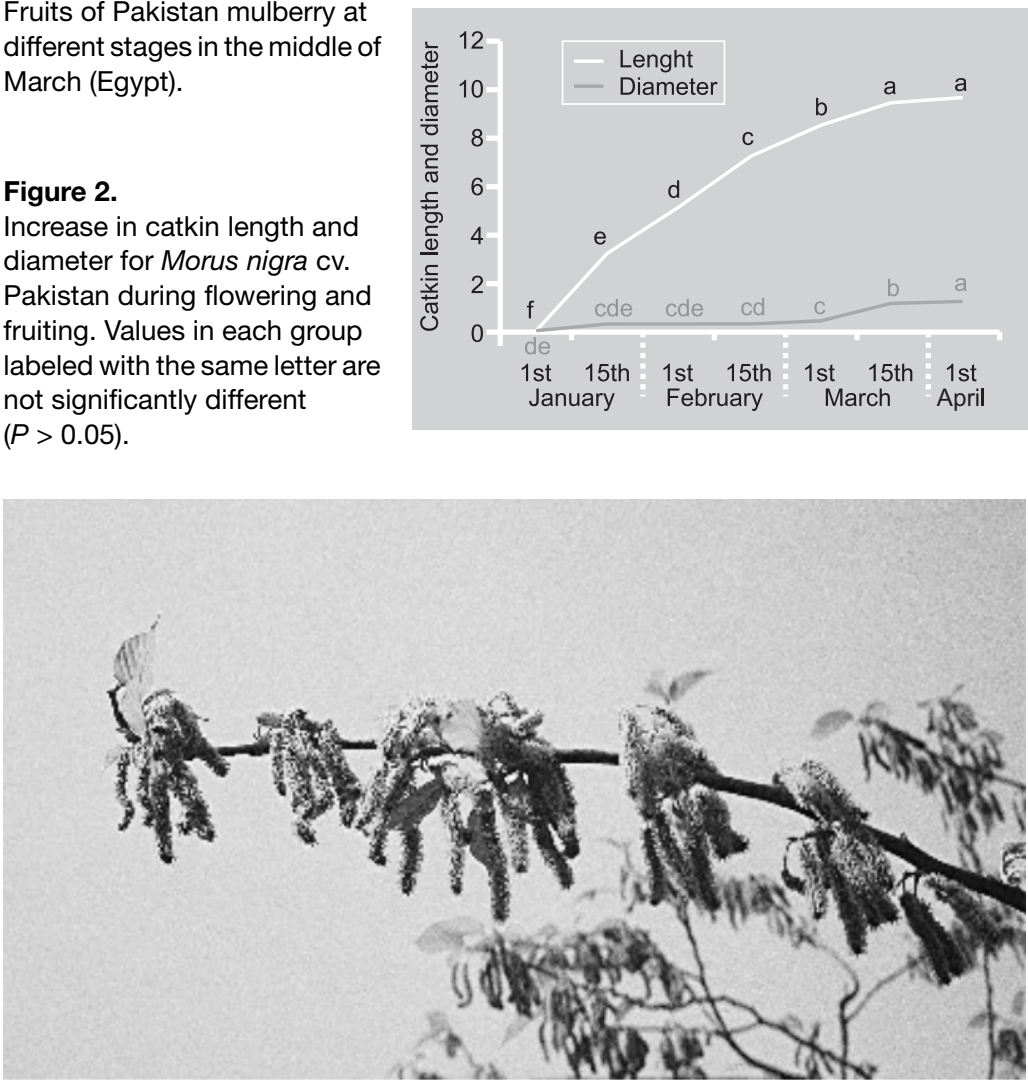

Figure 3.

Pakistan mulberry catkins developed earlier than the leaves during January and February (Egypt).
The Pakistan mulberry trees began to flower after 2 years of budding. Few flowers were developed during the first season of flowering. Intensive flowering and fruiting occurred in the third seasons (figure 1).
Catkins began to develop in the first week of January, reaching the full length in the second week of March (figure 2). Catkins appeared in the axils of leaves of the current season's growth and on spurs on the last season's wood (figure 3). Current season's branches were located at the top of the last season's wood followed by spurs.

Four to six catkins developed on each current growth or spur. No differences were found between the two seasons 2002 and 2003 in the average number of catkins developed per branch or spur.

The rate of leaf development was very low during flowering and early fruiting. At the end of fruiting, however, the rate of leaf development increased dramatically (figure 4).

Each catkin consisted of an average of 315 flowerlets (minute flower), stacked on a peduncle. Each flowerlet consisted of a single pistil tightly enveloped by four inconspicuous sepals. Each carpel or pistil consisted of a forked stigma, a short style and a spherical ovary.

Fruit ripening began in the second week of March and extended to the third week of April (figure 1). The elongate fruit of Pakistan mulberry was multiple, composed of numerous juicy drupelets (fruitlets). Each drupelet had arisen from an ovary of a separate flowerlet.

Ripening of the fruits began from the base on the current season's growth or spur. Ovaries began to swell within $48 \mathrm{~h}$ before full ripening. During ripening, fruits changed from the green stage to the ruby-red stage, then to the dark purple stage, becoming succulent and full of juice.

Besides the main season of flowering in the spring, Pakistan mulberry trees flower again in October. In this secondary season, fruit ripening occurred during November.

The developed fruits of Pakistan mulberry were seedless. Multiple catkins that we enclosed within isolation bags developed normal fruits. The parthenocarpic fruits matured and ripened normally, without need for pollination and seed formation. The taste panel assessments revealed that mulberry fruits without seeds tasted better. 
Usually, mulberry produces male and female catkins on different trees [20]. Wind pollination is necessary for ovary ripening that contains one seed within a single locule [7]. However, there are a few varieties of mulberry producing parthenocarpic fruits [20].

Fruits of Pakistan mulberry at the rubyred stage were sweet. However, excellent fruit flavor was associated with full fruit ripening, as assessed by sensory evaluation using the taste panels.

Fruits at the ruby-red stage changed color to dark-purple during storage. However, flavor was not as good as that of fruits ripened on trees, as panels were able to detect the differences. Studies on flavor have shown that the taste panel is one of the most effective methods of measuring this characteristic and is an essential component of any research in this area [21].

Ripe fruit ranged from $(7.3$ to 11.8$) \mathrm{cm}$ in length and from (1.3 to 1.5$) \mathrm{cm}$ in diameter (figure 5). Fruit weight ranged from (8.3 to 10.2) g. Such big fruit size of Pakistan mulberry facilitates the harvesting and handling processes. In addition, fruit of a bigger size is more attractive and easier to consume.

TSS of the fruit juice ranged from (13.0 to 17.5) ${ }^{\circ}$ Brix, with a mean of 15.25 , while $\mathrm{pH}$ ranged from 3.1 to 3.36 with a mean of 3.23 . Generally, black mulberry fruits have a good balance of sweetness and tartness that makes them the best flavored species of mulberry [3].

Solids and water constituted (86 and $14) \%$, respectively, of the fruits. Chemical analysis reveals that the fruits contained $10.2 \%$ carbohydrates, $1.4 \%$ protein and $1.2 \%$ fibers (figure 6 )

The percentage of fat in the fruits was $0.1 \%$. The lack of seeds, as the fruits were parthenocarpic, justifies the low concentration of fat.

Pakistan mulberry fruits were found to be a good source of iron, potassium, calcium and phosphorus (table I). The fruits were found to contain vitamin $\mathrm{C}$ at a medium level (37.5 mg $100 \mathrm{~g}^{-1}$ of fruits).

Generally, no significant differences in the fruit properties were found between the two seasons.

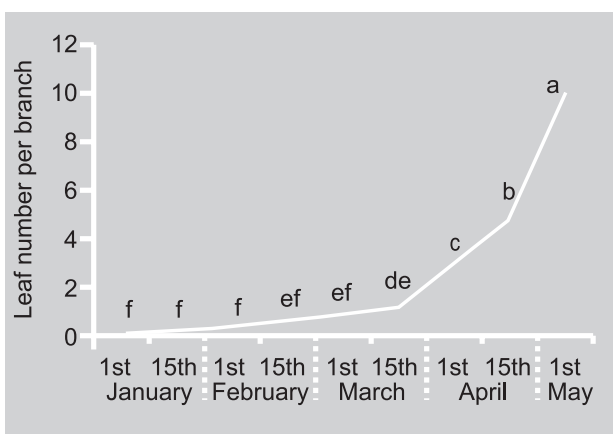

Figure 4.

Leaf development of Morus nigra cv. Pakistan during flowering and fruiting. Values labeled with the same letter are not significantly different $(P>0.05)$.
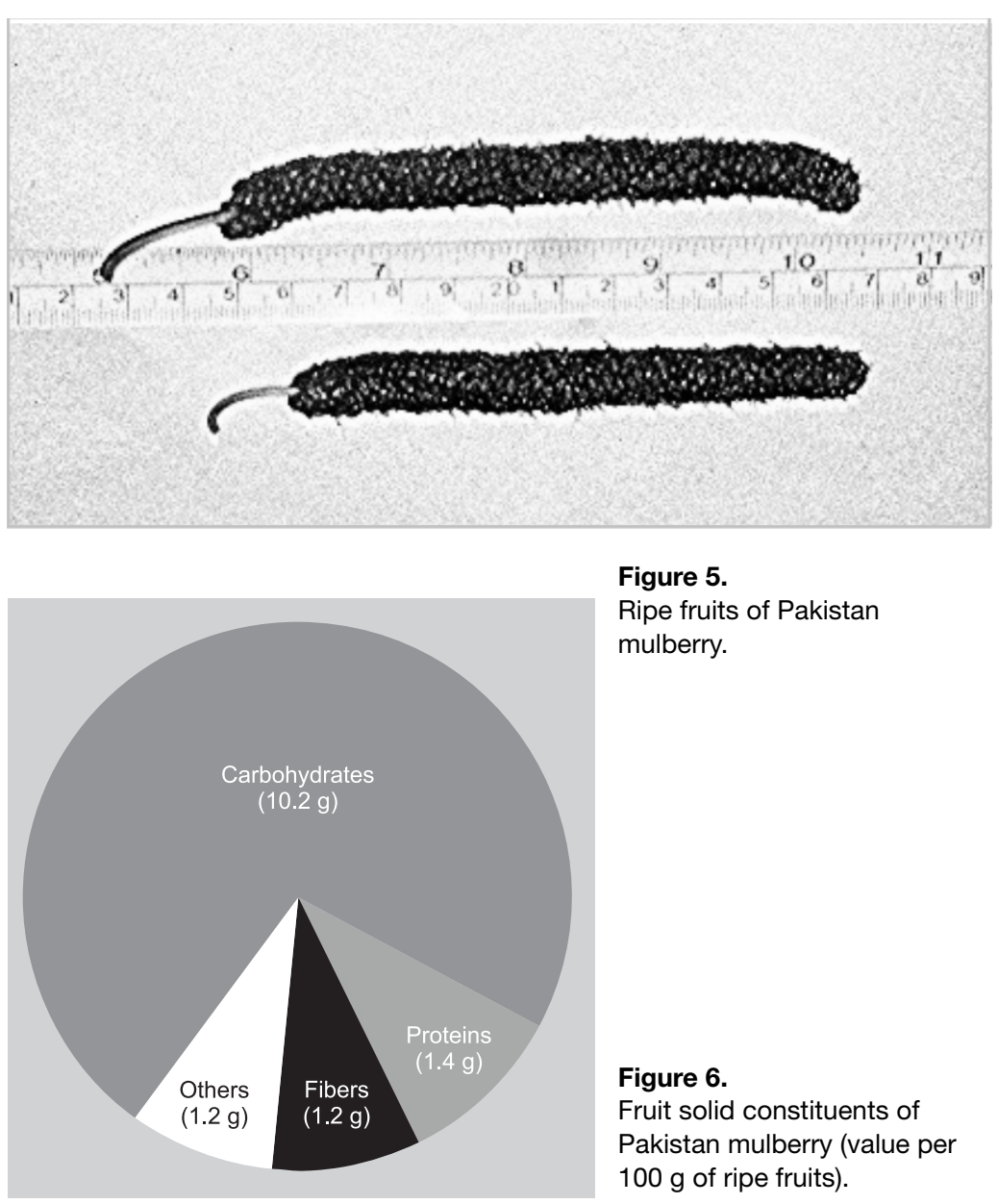

Figure 5.

Ripe fruits of Pakistan mulberry.

Figure 6.

Fruit solid constituents of Pakistan mulberry (value per $100 \mathrm{~g}$ of ripe fruits).
A surprising quantity of fruits can be gathered from a 3-year-old tree during the main season. Average crop production per tree in the second and third seasons was (51 and 96) kg, respectively. A mulberry tree takes many years to settle down and produce good crops of fruit, about 15 years being the 
Table I.

Composition of Pakistan mulberry fruits in calcium, iron, phosphorus and potassium.

\begin{tabular}{lc} 
Minerals & $\begin{array}{c}\text { Concentration } \\
\left(\mathrm{mg} \cdot 100 \mathrm{~g}^{-1} \text { of ripe fruits }\right)\end{array}$ \\
\hline Calcium (Ca) & 69.0 \\
Iron (Fe) & 1.8 \\
Phosphorus (P) & 42.0 \\
Potassium (K) & 202.0
\end{tabular}

norm [2]. The fruit yield produced in the fall is approximately $17 \%$ of the main crop.

One surprising observation is that Pakistan mulberry fruit juice was found not to cause staining. It was very easy to remove spots of juice from cloth with any detergent. However, the juice of the mulberry fruit is known to cause stains which are very difficult to remove, causing problems.

Ripe fruits began to be spoiled within 5 days of storage at room temperature. However, fruits can survive storage for 3 weeks at $3{ }^{\circ} \mathrm{C}$. Increasing the skin strength to avoid damage during handling and increasing the shelf life may be important parameters in Pakistan mulberry breeding programs, so the product can be retained for a longer period on the shelves of retail outlets [22].

\section{Conclusion}

In the Middle East and North Africa, the majority of the deserts lack enough rainfall which causes, in many places, an increase in water-soluble salts close to the surface. As a result, salinity has long been recognized as one of the most critical issues facing countries in the Middle East and North Africa.

Pakistan mulberry trees were cultivated successfully under saline soil conditions. Pakistan mulberry can be an alternative crop to be cultivated in the saline marginal lands in the region.

Pakistan mulberry trees produce fruits in March and April, when there are very few fruits in the local market in the region. The nutritional and therapeutic properties of
Pakistan mulberry fruits make them suitable for processing. The big fruit size of Pakistan mulberry facilitates the harvesting and handling processes, and fresh consumption.

Pakistan mulberry may become the basis for industries, giving the inhabitants of the marginal lands in the Middle East a way of making a living. In addition, planting the degraded areas with plant species tolerant to salinity could have an important ecological role in combating desertification in the region.

\section{References}

[1] Reich L., Uncommon fruits worthy of attention: a gardener's guide, Addison-Wesley Publ. Co, New York, USA, 1991.

[2] Sanjappa M., Geographical distribution and exploration of the genus Morus L. (Moraceae), in: Sengupta K., Dandin S.B. (Eds.), Genetic resources of mulberry and utilization, Cent. Sericult. Res. Train. Inst., Mysore, India, 1989.

[3] Darias-Martin J., Lobo-Rodrigo G., Hernandez-Cordero J., Diaz-Diaz E., DiazRomero C., Alcoholic beverages obtained from black mulberry, Food Technol. Biotech. 41 (2003) 173-176.

[4] Andallu B., Suryakantham V., Lakshmi Srinkanthi B., Reddy G.K., Effect of mulberry therapy on plasma and erythrocyte membrane lipids in patients with type 2 diabetes, J. Clin. Chem. 314 (2001) 47-53.

[5] Duke J.A., The quest for tolerant germplasm, in: Jung J.A., Crop tolerance to suboptimal land conditions, Am. Soc. Agron., Madison, Wisconsin, USA, 1978, pp. 1-61.

[6] Rayns F.W., Development and use of cell lines for specific purposes, in: In vitro cultivation of plant cells, Butterworth-Heinemann Ltd., Oxford, UK, 1993, pp. 65-86.

[7] Hiroaki M., Akio K., Hiroaki Y., Mulberry breeding, cultivation and utilization in Japan, in: Sanchez M.D. (Ed.), Mulberry for animal production, FAO Anim. Prod. Health, Pap. 147, Rome, Italy, 2002, pp. 63-71.

[8] Trenkel M.E., Improving fertilizer use efficiency, controlled-release and stabilized fertilizers in agriculture, Int. Fertil. Ind. Assoc., Paris, France, 1997.

[9] Bramlett D.L., Askew G.R., Blush T.D., Bridgwater F.E., Jett J.B., Advances in pollen 
management, in: Agriculture Handbook, USDA For. Serv., Washington, DC, USA, 1993.

[10] Goldstein I.J., Hayes C.E., The lectins: carbohydrate-binding proteins of plants and animals, Adv. Carbohydr. Chem. Biochem. 35 (1978) 1978.

[11] Cottenie A., Soils and plant testing as a basis of fertilizer recommendation, $\mathrm{AO}$ Soil Bull. No. $3812,1980$.

[12] Plummer D.T., An introduction to practical biochemistry, McGraw Hill Book Co. Ltd., UK, 1971.

[13] Anon., Official methods and recommended practices of the American Oil Chemists Society, AOCS Press, Champaign, USA, 1996.

[14] Anon., Total, soluble, and insoluble dietary fiber in foods: enzymatic-gravimetric method, MES-TRIS buffer, in: Association of Official Analytical Chemists (Ed.), Official methods of analysis, 15th ed., 3rd suppl., J. Assoc. Off. Anal. Chem. Int., Arlington, VA, USA, 1992.

[15] Anon., Definition and analysis of complex carbohydrates/dietary fiber, in: Association of Official Analytical Chemists (Ed.), Proc.
Workshop on Complex Carbohydrates and Dietary Fiber, AOAC, Nashville, TN, USA, 1995.

[16] Morton S., Roberts D., ATI unicam, atomic absorption spectrometry - methods manual, Issue 2, Unicam Ltd, London, UK, 1991, p. 398.

[17] Smirnoff N., Ascorbic acid: metabolism and function of a multifaceted molecule, Curr. Opin. Plant Biol. 3 (2000) 229-235.

[18] Duncan D.B., Multiple range and multiple F test, Biometrics 11 (1955) 1-42.

[19] Facciola S., Cornucopia: a source book of edible plants, Kampong Publ., Ca, USA, 1990.

[20] Johns L., Stevenson V., Fruit for the home and garden, Angus and Robertson (Eds), Sydney, Australia, 1985.

[21] Civille G.V., Lyon B.G., Aroma and flavor lexicon for sensory evaluation: terms, definitions, references, and examples, Am. Soc. Test. Mater., Spiral ed., Philadelphia, USA, 1996.

[22] Dandin S.B., Mulberry improvement programmes for sustained productivity under tropics, in: Devaiah M.C., Narayanaswamy K.C., Maribashetty V.G. (Eds.), Advances in mulberry sericulture, CVG Publ., Bangalore, India, 1999, pp. 51-87.

\section{Floración y fructificación de la morera cv. 'Pakistán' en suelos salinos en Egipto.}

Resumen - Introducción. La introducción de una variedad elite de mora negra en zonas caracterizadas por suelos salinos podría tener, a largo plazo, un impacto significante en el desarrollo de sectores rurales desfavorecidos. Material y métodos. Las plantas de la morera cv. 'Pakistán' se propagaron mediante injerto sobre jóvenes plántulas de morera de tipo japonés. Los árboles se cultivaron en suelos salinos en Egipto. Resultados y discusión. Los árboles florecieron favorablemente y fructificaron 2 años después de su injerto. Las floraciones y fructificaciones intensivas tuvieron lugar en el momento de la tercera temporada. Se desarrollaron entre cuatro a cinco amentos en cada rama o brazo. Cada amento se compuso de media de 315 flores elementares apiladas sobre una caña floral. Las frutas resultaron ser de partenocarpia. Durante su madurez, el color de las frutas se desarrolló del estado verde al estado rojo rubí y acto seguido, al estado púrpura oscuro. La madurez de la fruta comenzó en la segunda semana de marzo y se prolongó hasta la tercera semana de abril. La fruta madura midió $(7,3$ a 11,8) $\mathrm{cm}$ de largo y $(1,3$ a 1,5$) \mathrm{cm}$ de ancho. Su peso varió de $(8,3$ a 10,2$) \mathrm{g}$. El valor de los SST del jugo de la fruta varió de $(13,0 \text { a } 17,5)^{\circ}$ Brix, mientras que el $\mathrm{pH}$ se escalonaba de 3,1 a 3,36. Las frutas presentaron un $10,2 \%$ de hidratos de carbono, un $1,4 \%$ de proteína y un $1,2 \%$ de fibras. Resultaron ser una buena fuente de hierro, de potasio, de calcio y de fósforo. Su contenido en vitamina $\mathrm{C}$ fue medio. La producción media por árbol fue de $51 \mathrm{~kg}$ en la segunda temporada y de $96 \mathrm{~kg}$ en la tercera temporada. El almacenamiento de frutas maduras no pudo sobrepasar 5 días en temperatura ambiente; pero, a temperatura fría, pudo alcanzar 3 semanas.

Egipto / Morus nigra / introducción de plantas / salinidad del suelo 